\title{
Expansion of the macroalga Caulerpa racemosa and changes in softbottom macrofaunal assemblages in Moni Bay, Cyprus
}

\author{
Marina ARGYROU*, Andreas DEMETROPOULOS, Myroula HADJICHRISTOPHOROU
}

Marine Biology and Ecology Section, Department of Fisheries, Ministry of Agriculture, Natural Resources and Environment, 13 Aeolou Street, 1416 Nicosia, Cyprus

(Received 27 July 1998, revised 8 June 1999, accepted 16 August 1999)

\begin{abstract}
The recent expansion of the Red Sea macroalga Caulerpa racemosa and its impact on the diversity and abundance of macrobenthos were examined and compared in the summers of 1992 and 1997, in Moni Bay, Cyprus. The phytobenthic community of the bay in 1992 was dominated by the seagrass Posidonia oceanica while, in 1997, the Lessepsian migrant $C$. racemosa became the most dominant, forming extensive mats. Changes in the vegetation system in Moni Bay have caused significant compositional changes in macrofaunal assemblages. A total of 178 individuals of 62 species are recorded. The composition of the macrofauna in 1992 was dominated by gastropods ( $44 \%$ ), crustaceans ( $22 \%$ ), bivalves $(17 \%)$, polychaetes $(11 \%)$ and echinoderms $(6 \%)$. In 1997, the gastropods and crustaceans had decreased to $13 \%$ and $16 \%$ respectively, while, polychaetes had increased to $38 \%$ becoming the most dominant taxon. Bivalves and echinoderms also increased to $22 \%$ and $11 \%$, respectively, in 1997 . The proliferative growth of C. racemosa imposed successional changes on the macrofaunal asscmblages in Moni Bay, Cyprus, between 1992 and 1997. It remains to be tested whether the expansion of $C$. racemosa is related to the increase of water temperature associated with global warming or nutrient inputs or with the differences in the life history characteristics of this migrant vs. native algal species. (C) 1999 Ifremer / CNRS / IRD / Éditions scientifiques et médicales Elsevier SAS
\end{abstract}

Lessepsian migrant / Caulerpa racemosa / benthos / community composition / Moni Bay, Cyprus

Résumé - Expansion de la macroalgue Caulerpa racemosa et variations de la macrofaune des fonds meubles dans la baie de Moni, Chypre. L'expansion récente de la macroalgue de mer Rouge Caulerpa racemosa et son impact sur la diversité et l'abondance du macrobenthos ont été comparés dans la baie de Moni, à Chypre, entre les étés 1992 et 1997. La communauté phytobenthique de la baie était dominée en 1992 par l'algue Posidonia oceanica, alors qu'en 1997, l'immigrant lessepsien $C$. racemosa dominait, formant de vastes prairies. Les changements de végétation dans la baie de Moni ont entraîné des modifications significatives dans la composition de la macrofaune. Au total, 178 individus de 62 espèces ont été examinés. La composition de la macrofaune était dominée en 1992 par les gastéropodes (44\%), les crustacés $(22 \%)$, les bivalves (17\%), les polychètes (11\%) et les échinodermes $(6 \%)$. En 1997, les gastéropodes et les crustacés étaient réduits à 13 et $16 \%$ respectivement, tandis que le polychètes devenaient le taxon dominant (38\%); les bivalves et les échinodermes progressaient également jusqu'à 22 et $11 \%$ respectivement. La croissance proliférante de C. racemosa a provoqué une série de changements dans la macrofaune de la baie de Moni entre 1992 et 1997. Il reste à établir si l'expansion de C. racemosa est due à l'élévation de la température de l'eau associée au réchauffement global, à l'apport des nutriments, ou aux différences entre les caractéristiques de l'évolution de cet immigrant et celles des espèces algales indigènes. (C) 1999 Ifremer / CNRS / IRD / Éditions scientifiques et médicales Elsevier SAS

immigrant lessepsien / Caulerpa racemosa / benthos / communauté / baie de Moni, Chypre

\footnotetext{
* Correspondence and reprints
} 


\section{INTRODUCTION}

The construction of the Suez Canal in 1869, linking the southeastern corner of the Mediterranean with the northen tip of the Gulf of Suez, Red Sea, provided unrivalled opportunities for marine organisms to extend their geographical ranges $[19,21,23,27]$. The Suez Canal, once established as a pathway of Lessepsian migration (i.e. migration of organisms through the Suez Canal into the Mediterranean), has brought a considerable number of marine species into the Mediterranean during the last few decades. Only relatively few organisms migrated in the opposite direction [27,28], probably because of prevailing current flows, but the reasons for this are not yet clear. As a whole, the influx of Red Sea species into the Mediterranean has been 'successful', as a considerable number of Red Sea species have become well adapted to the new environment. It has been estimated that Lessepsian migrants constitute nearly $5 \%$ of the total marine fauna of the Mediterranean in comparison to $12 \%$ found in the southeastern Mediterranean [11]. In fact, about $20 \%$ of the decapod species off the Israeli Mediterranean coast are represented by the Indo-Pacific Erythracan fauna [12].

The migration of benthic marine plants (seagrasses and macroalgae) from the Red Sea into the Mediterranean has also been successful [20]. Several Red Sea plant species have been reported from the Mediterranean, among those the seagrass Halophila stipulacea which grows intermingled with the immigrant Caulerpa racemosa [20]. The seagrass $H$. stipulacea was the first Red Sea immigrant via the Suez Canal to be reported from the Mediterranean [21]. At present, this species is common in the waters around Rhodes, in the Aegean Sea, in the waters of Cyprus, on the coast of Egypt and all along the Suez Canal $[1,16,14]$. On the other hand, the green alga C. racemosa, which is very common in the Red Sea, was found at various stations in the eastern Mediterranean in both underdeveloped and developed forms [20].

Over recent years, C. racemosa has been undergoing prolific growth in the coastal waters of Cyprus. This species was first reported in 1991 in Moni Bay [13] at a depth of $30 \mathrm{~m}$. At present, it can be found all around the island forming extensive dense beds. Other Red Sea migrants, such as the filamentous green alga Cladophora patentiramea (Boudouresque and Verlaque, pers. comm.) and the brown alga Stypopodium schimperi, have caused considerable ecological problems on our coastline in recent years [14].
The need to understand what is triggering the rapid expansion of C. racemosa off the coast of Cyprus is crucial, since the colonization of this migrant is in a 'dynamic on-going process' which may cause serious ecological problems, such as habitat alterations and vital changes in macrobenthic assemblages. Changes in the vegetation type of an ecosystem may cause dramatic changes in macrofaunal assemblages [17] and, subsequently, may alter the dynamics of the whole ecosystem. It is generally shown that macrofaunal communities can be used as indicators, since they respond predictably to environmental perturbations [3].

The aim of this study was to summarize the present expansion of the Lessepsian migrant $C$. racemosa in the coastal waters of Cyprus and to examine the possible effects of the proliferation of this species on the softbottom macrofaunal assemblages. Macrobenthic data (phytobenthos and zoobenthos) were collected in Moni Bay, Cyprus, before (1992) and after (1997) the occur-rence of $C$. racemosa. The diversity and abundance data of zoobenthos, before and after the spread of $C$. racemosa, were used to characterize the community structure, and to compare possible alterations in macroinvertebrate composition associated with the recent colonization of C. racemosa.

\section{MATERIALS AND METHODS}

\subsection{Site Description}

The study area (figure 1) is located in Moni Bay, adjacent to the city of Limassol which is the largest coastal city in Cyprus. Close to the study area, about $450 \mathrm{~m}$ from the sampling stations, a sewage outfall discharges approximately $6000 \mathrm{~m}^{3} \mathrm{~d}^{-1}$ tertiary effluents, at a depth of $5 \mathrm{~m}$. In addition, an open sea cage-culture farm, with a production of about $100 \mathrm{t} \mathrm{yr}^{-1}$ is located near the sampling area, at a distance of about $500 \mathrm{~m}$.

The phytobenthic communities found in the area consist mainly of the meadows of the seagrass Posidonia oceanica which are the most important habitats in the Mediterranean. Posidonia forms extensive meadows in the area starting from shallow waters $(5 \mathrm{~m}$ depth) and extending down to over $30 \mathrm{~m}$ depth [13]. In 1991, the Red Sea migrant Caulerpa racemosa was found for the first time, in Moni Bay, at a depth of $30 \mathrm{~m}$. Since then, denselyformed beds of $C$. racemosa have been rapidly expanding around the island, with its greatest abundance in the 


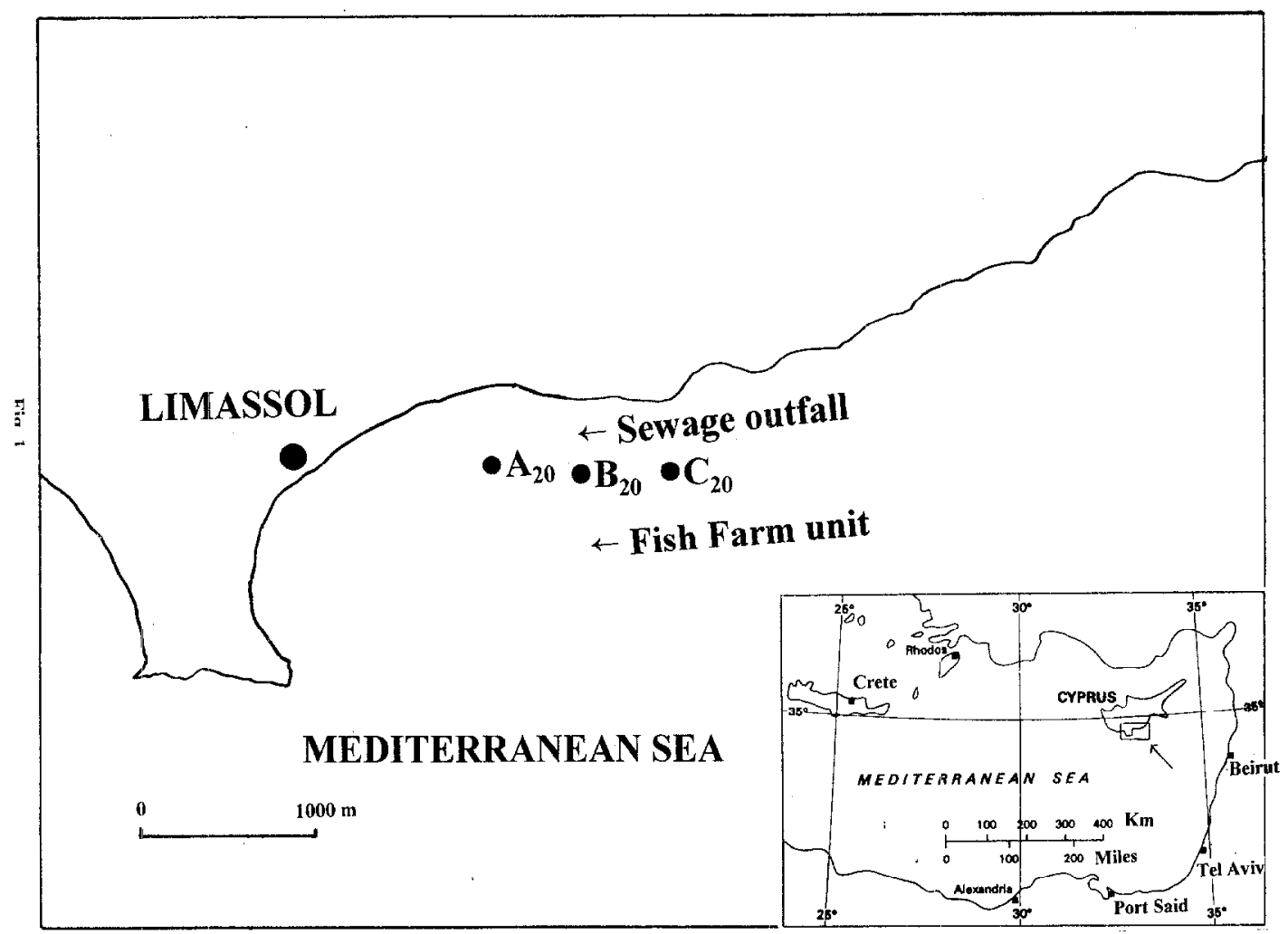

Figure 1. Map of Moni Bay, showing the three stations sampled during summers 1992 and 1997, before and after the proliferation of Caulerpa racemosa.

southern regions (Limassol-Moni Bay). C. racemosa has been found to occupy a wide range of habitats, from sandy to muddy substrates, from the intertidal zone down to $60 \mathrm{~m}$ depth [15].

\subsection{Sampling Regime}

Three stations $\left(A_{20}, B_{20}, C_{20}\right)$, located in Moni Bay at $20 \mathrm{~m}$ depth were sampled during the summers of 1992 (before the appearance of C. racemosa at this depth) and 1997 (figure 1). Each station was positioned using an echosounder and an Interphase Star Pilot 6 GPS (Global Positioning System) unit. Stations were at a distance of about $500 \mathrm{~m}$ from each other and about $650 \mathrm{~m}$ from the coast. During the summers of 1992 and 1997, sediment and macrobenthic samples were collected by the RV Alkyon from all three stations.

\subsection{Sediment Characteristics}

Granulometric analyses on surficial sediments were conducted using a series of sieves $(2.36 \mathrm{~mm}, 1.18 \mathrm{~mm}$,
$0.6 \mathrm{~mm}, 0.3 \mathrm{~mm}, 0.15 \mathrm{~mm}, 0.075 \mathrm{~mm}$ ) to separate out the gravel fraction, very coarse sand, coarse sand, medium sand, fine sand, and very fine sand [18].

Percent organic matter was measured by weight loss upon combustion at $500{ }^{\circ} \mathrm{C}$ for $16 \mathrm{~h}$.

\subsection{Macrobenthos}

At each station, ten macrobenthic samples were obtained with an "orange peel" grab sampler $\left(0.14 \mathrm{~m}^{2}\right)$ and pooled together, covering a total surface area of $1.45 \mathrm{~m}^{2}$. Sediment samples were then filtered through a $500 \mathrm{~mm}$ sieve to collect macrofauna, algae and seagrasses. After collection, specimens were preserved in $70 \%$ alcohol and identified to the lowest possible taxa using the following sources $[4-10,22,24,25,29,31]$.

\subsection{Statistical Analysis}

An $\mathrm{F}_{\max }$ was used prior to Anova to check for homogeneity of variances. One-way Anova was used to test for significant effects between species diversity, abundance 


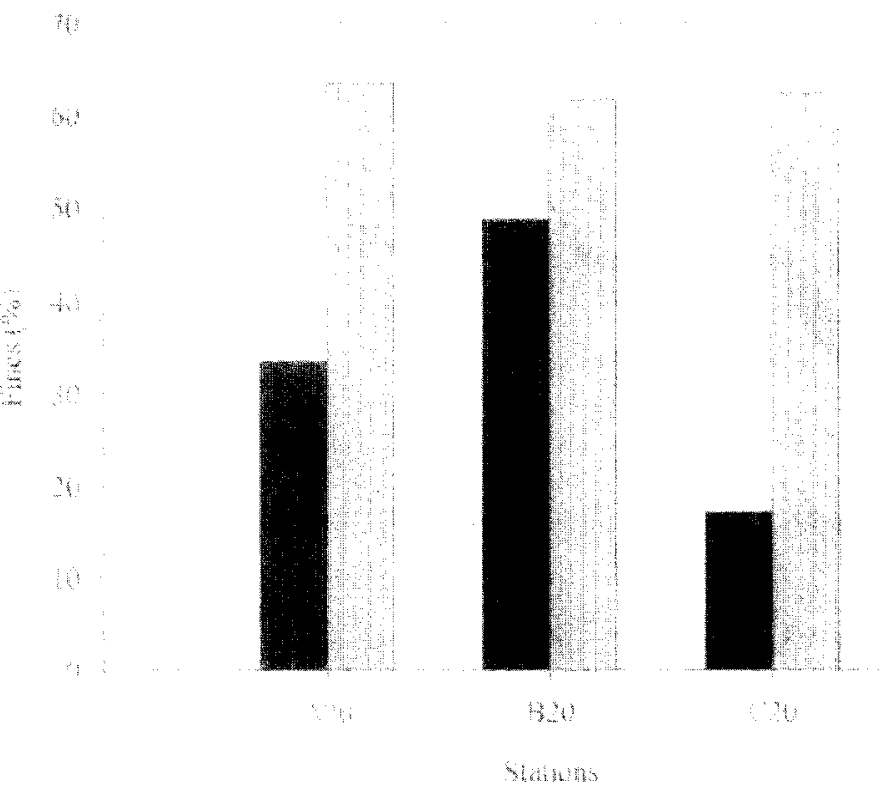

I.

antom

Figure 2. Percent fines (\%) in sediments of Moni Bay for all three stations, from summers 1992 and 1997.

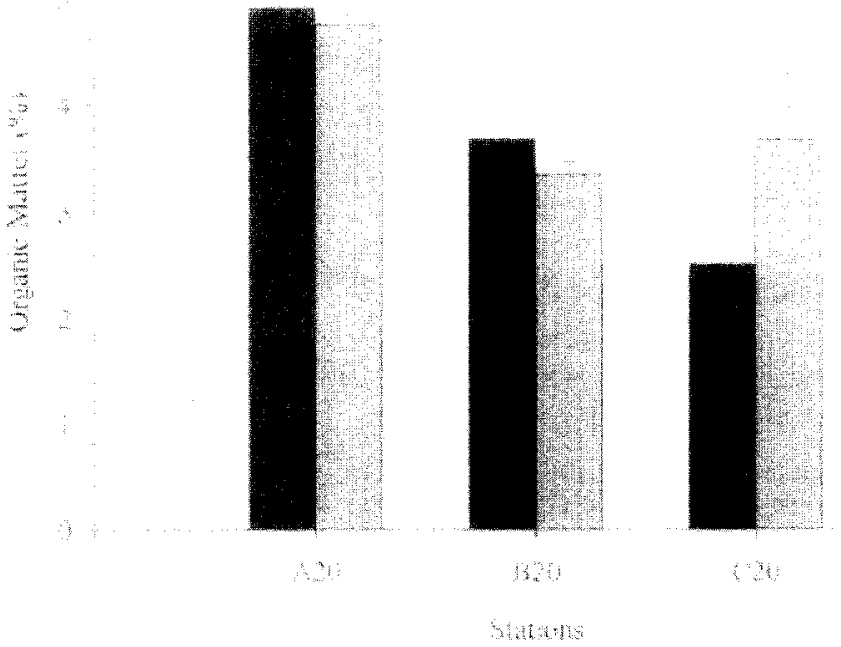

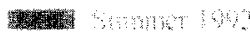

s.m?

Figure 3. Percent organic matter $(\%)$ in sediments of Moni Bay for all three stations, from summers 1992 and 1997. 
Table I. Macrobenthic diversity and abundance data for all 3 stations sampled off the Moni Bay, Cyprus, during Summers 1992 and $1997 * *=40 \%-60 \%$ coverage; $* * *=70 \%-90 \%$ coverage; $p=$ present; numbers $=$ number of individuals of each species per $1.45 \mathrm{~m}^{2}$ surface area.

\begin{tabular}{llllllll}
\hline Classification & \multicolumn{3}{c}{1992} & & & \multicolumn{2}{c}{1997} \\
\cline { 2 - 3 } \cline { 5 - 7 } & $A_{20}$ & $B_{20}$ & $C_{20}$ & & $A_{20}$ & $B_{20}$ & $C_{20}$ \\
\hline
\end{tabular}

\section{ALGAE}

$\begin{array}{llllll}\mathbf{A}_{20} & \mathbf{B}_{20} & \mathbf{C}_{20} & \mathbf{A}_{20} & \mathbf{B}_{20} & \mathbf{C}_{20}\end{array}$

\section{CHLOROPHYCEAE}

Caulerpaceae

Caulerpa prolifera

Caulerpa racemosa

Dasycladaceae

Dasycladus clavaeformis

Codiaceae

Udotea petiolata

PHAEOPHYCEAE

Diclyolaceat

Dilophus mediterraneus

ANGIOSPERMAE

Potamogetomaceae

Posidonia oceanica

\section{ANNELIDA}

POLYCHAETA

Eunicidae

Eunice floridana

Marphysa sanguinea

Marphysa bellii

Capitellidae

Capitella sp.

Pseudocapitella incerta

Onuphidae

Onuphis eremita

Glyceridae

Glycera convoluta

Nephtyidae

Nephtys hombergii

Nereidae

Neanthes pelagica

Aphroditidae

Aphrodita aculeata

Hermonia hystrix

Syllidae

Exogone gemmifera

Goniadidae

Goniada norvegica

Pectinariidae

Amphictene auricoma

Orbiniidae

Naineris laevigata

Sigalionidae

Sthenelais boa

SIPUNCULIDA

Sipunculidae

Phascolosoma sp.
Table I. (continued).

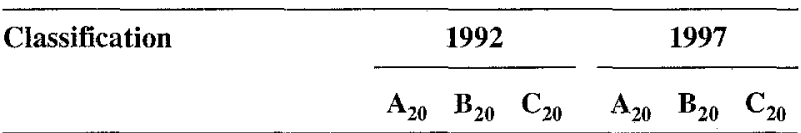

\section{MOLLUSCA}

PLACOPHORA

Chitonidae

Chiton olivaceus

GASTROPODA

Columbellidae

Columbella rustica

Turbinidae

Bolma rugosa

Cerithiidae

Cerithium vulgatum

Conidae

Conus mediterraneus

Trochidae

Jujubinus exasperatus

Pyramidellidae

Euparthenia bulinea

Neritidae

Smaragdia viridis

Tricoliidae

Tricolia speciosa

Turritellidae

Turritella turbona

Philinidae

Philine catena

LAMELLIBRANCHIATA

Turridae

Bela nebula

Tellinidae

Tellina balaustina

Semelidae

Abra alba

Carditdae

Glans aculeata

Cardiidae

Parvicardium exiguum

Plagiocardium papillosum

Pectinidae $s$

Lissopecten hyalinus

Lucinidae

Loripes lacteus

Myrtea spinifera

Veneridae

Gouldia minima

Venus verrucosa

Glycymeridae

Glycymeris glycymeris

Mytilidae

Modiolula phaseolina
228

$1 \quad 1$

$\begin{array}{llllll}3 & 2 & 3 & 3 & 1 & 2\end{array}$
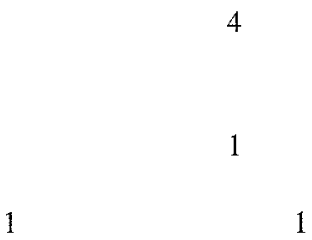

2

21

2

11

1

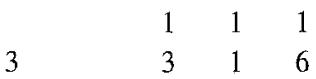

1 
Table I. (continued).

\begin{tabular}{|c|c|c|c|c|c|c|}
\hline \multirow[t]{2}{*}{ Classification } & \multicolumn{3}{|c|}{1992} & \multicolumn{3}{|c|}{1997} \\
\hline & $\mathbf{A}_{20}$ & $\mathbf{B}_{20}$ & $\mathrm{C}_{20}$ & $\mathbf{A}_{20}$ & $\mathrm{~B}_{20}$ & $\mathrm{C}_{210}$ \\
\hline \multicolumn{7}{|l|}{ ARTHROPODA } \\
\hline \multicolumn{7}{|l|}{ CRUSTACEA } \\
\hline \multicolumn{7}{|l|}{ Decapoda } \\
\hline \multicolumn{7}{|l|}{ Alpheidae } \\
\hline Athanas nitescens & 1 & & & & & \\
\hline \multicolumn{7}{|l|}{ Processidae } \\
\hline Processa edulis & & & & & & 1 \\
\hline \multicolumn{7}{|l|}{ Paguridae } \\
\hline Cestopagurus timidus & 2 & & 2 & 3 & 2 & \\
\hline \multicolumn{7}{|l|}{ Diogenidae } \\
\hline Clibanarius erythropus & 1 & & & 2 & 1 & 1 \\
\hline \multicolumn{7}{|l|}{ Paguristes eremita } \\
\hline Eriphiidae & & & 1 & 1 & & \\
\hline Eriphia verrucosa & 1 & & & & & \\
\hline \multicolumn{7}{|l|}{ Dorippidae } \\
\hline Ethusa mascarone & & 1 & & & 1 & \\
\hline \multicolumn{7}{|l|}{ Galatheidae } \\
\hline Galathea squamifera & & 1 & & 1 & & \\
\hline \multicolumn{7}{|l|}{ Portunidae } \\
\hline Liocarcinus arcuatus & 2 & & & & & \\
\hline \multicolumn{7}{|l|}{ Liocarcinus corrugatus } \\
\hline Liocarcinus maculatus & & & 1 & & & \\
\hline Majidae & & & & 1 & & \\
\hline Inachus dorsettensis & & & & & 1 & \\
\hline \multicolumn{7}{|l|}{ Isopoda } \\
\hline \multicolumn{7}{|l|}{ Sphaeromatidae } \\
\hline Sphaeroma sematum & 1 & & & & & \\
\hline \multicolumn{7}{|l|}{ Amphipoda } \\
\hline \multicolumn{7}{|l|}{ Gammaridae } \\
\hline Gammaridae sp. & & & & 2 & & 1 \\
\hline \multicolumn{7}{|l|}{ ECHINODERMATA } \\
\hline \multicolumn{7}{|l|}{ HOLOTHUROIDEA } \\
\hline Holothuriidae & & & & & & \\
\hline Holothuria mammata & & & 1 & & & \\
\hline ECHINOIDEA & & & & & & \\
\hline Loveniidae & & & & & & \\
\hline Echinocardium cordatum & & & & 3 & & \\
\hline Fibulariidae & & & & & & \\
\hline Echinocyamus pusillus & & & & 5 & & \\
\hline Schizasteridae & & & & & & \\
\hline Schizaster canaliferus & & 1 & & & & \\
\hline OPHILROIDFA & & & & & & \\
\hline Amphiuridae & & & & & & \\
\hline Amphiura chiajei & & 1 & & & 3 & \\
\hline Ophiuridae & & & & & & \\
\hline Ophiura albida & & & & & 1 & 1 \\
\hline Ophiodermatidae & & & & & & \\
\hline Ophioderma longicaudum & 1 & & & & & \\
\hline
\end{tabular}

and sediment characteristics [26]. When Anova differences were significant (i.e. $p<0.05$ ), a Scheffé multiple range test was performed to detect for differences $(p<0.05)$ between stations and sampling dates. Pearson Product-Moment Correlation analysis was also performed to test for relationships between all variables.

\section{RESULTS}

\section{Sediment Characteristics}

Sediments generally consisted of $95 \%$ sand (fine, medium, coarse) at all stations in both sampling periods. Fines expressed as a percentage of sediment particles smaller than $0.075 \mathrm{~mm}$ ranged between 17.10 $48.65 \%$ at all stations in summer 1992, while, in summer 1997, this had a range of 61.60-63.40\% (figure 2). There were significant differences in grain size distribution between the sampling periods $(P<0.05)$. In 1997 , the percent of fines was significantly higher $(P<0.05)$ than that of 1992.

Percentage of organic matter ranged from $2.52 \%$ to $4.90 \%$ in all stations, for both sampling periods (figure 3). No significant differences $(P>0.05)$ in organic matter concentrations were observed between stations and between sampling dates. Despite the fact that the percentage of fines in sediments from all stations significantly increased in 1997 compared to 1992, there was no concomitant increase in the concentration of the sedimentary organic matter. The exact reason for this is not clear, but it is likely to be due to high degradation rates.

A total of 178 individuals belonging to 62 species were counted and identified in both sampling periods (table 1 ). The five most abundant macrofauna taxa in Moni Bay were polychaeta, gastropoda, bivalvia, crustacea and echinodermata.

The composition of the benthos in 1992 represents the original benthic community prior to environmental disturbances caused by the expansion of the Lessepsian migrant C. racemosa (table 1). The majority of the benthic community in the pre-disturbance period consisted of gastropods (44\%), followed by crustaceans $(22 \%)$, bivalves $(17 \%)$, polychaetes $(11 \%)$, and echinoderms (6\%) (figure 4). In 1997, the contribution of gastropods decreased to $13 \%$, and the contribution of polychaetes increased to $38 \%$, becoming the most dominant taxon (figure 4). Bivalves and echinoderms 

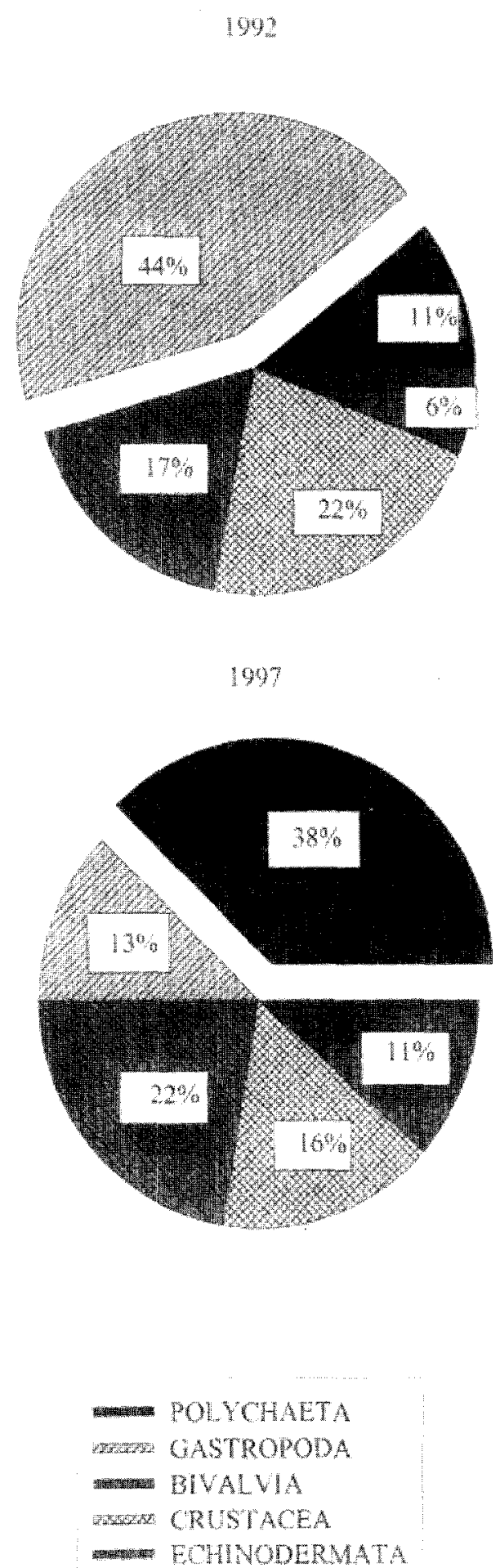

Figure 4. Percentage abundances of dominant macrofaunal groups from all stations of Limassol Bay, from summers 1992 and 1997. increased to $22 \%$ and $11 \%$, respectively, while crustaccans decreascd to $16 \%$ (figure 4 ).

The number of species per $1.45 \mathrm{~m}^{2}$ surface area ranged from 12 to 15 in the summer of 1992 , while in the summer of 1997 the range was 19 to 26 (figure 5). In 1997, the number of species significantly $(P<0.05)$ increased at all stations, compared to 1992. In fact, significant $(P<0.05)$ increases in the polychaete species were observed at all stations in 1997 (figure 6). Total species number was significantly correlated with fine sediments $(\mathrm{R}=0.80)$ and $\mathrm{OM}$ concentrations $(\mathrm{R}=0.85)$.

Macrofaunal abundance ranged from 19 to 23 in 1992 and from 32 to 44 in 1997 (figure 7). There were significant differences $(P<0.05)$ in macrofaunal abundance between sampling dates, with the highest abundance occurring in the summer of 1997. High abundance of polychaete species corresponded to the total increase of macrofaunal abundance in 1997 (figure 8). Polychaete abundance increased significantly $(P<0.05)$ in the summer of 1997 compared to the summer of 1992, suggesting that the proliferation of the Red Sea macroalga C. racemosa favoured their abundance. Total macrofauna abundance was positively correlated with finegrained sediments $(\mathrm{R}=0.68)$ and $\mathrm{OM}$ concentrations $(R=0.63)$ at all stations for both periods.

\section{DISCUSSION}

\subsection{Macrobenthic community structure}

In 1992, the seagrass Posidonia oceanica was uniformly distributed in all stations with a scattered appearance of the green alga Caulerpa prolifera at station $\mathrm{B}_{20}$ (table I). In 1997, the seagrass Posidonia oceanica occurred at stations $\mathrm{A}_{20}$ and $\mathrm{C}_{20}$, while the green alga C. racemosa dominated in densely extensive beds at all stations (table 1). The green algae Dasycladus clavaeformis and Udotea petiolata, as well as the brown alga Dilophus mediterraneus had a scattered distribution among stations (table 1).

Since 1991, when C. racemosa was observed in the Moni Bay, at a depth of $30 \mathrm{~m} \mathrm{[13],} \mathrm{this} \mathrm{species} \mathrm{has} \mathrm{been} \mathrm{under-}$ going proliferative growth around most of the island. This species has successfully colonized a wide range of habitats (mainly sandy or muddy bottoms) and depths, and can be found from the intertidal zone down to $60 \mathrm{~m}$ depth [15]. The overwhelming expansion of this Red Sea 


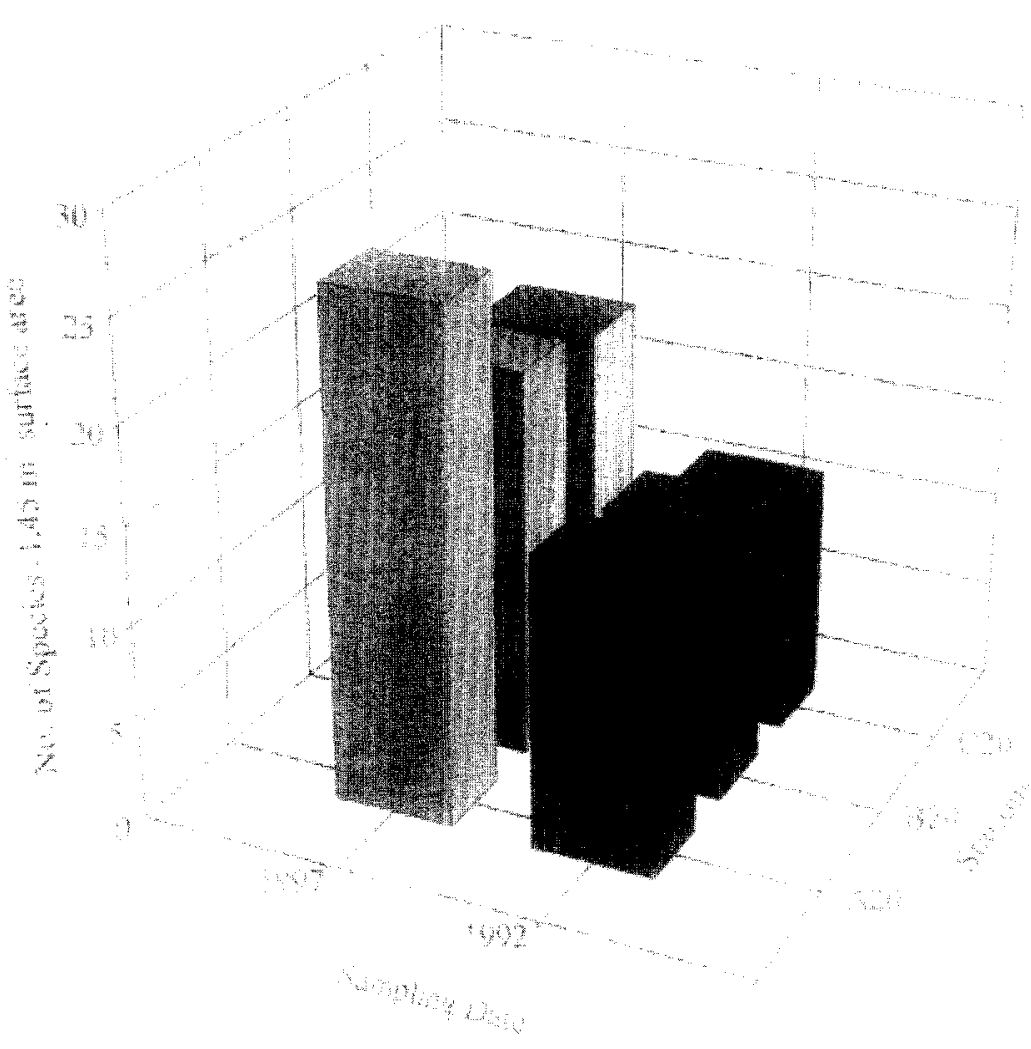

Figure 5. Number of macrofaunal Species per $1.45 \mathrm{~m}^{2}$ surface area, from all three stations of Moni Bay, from summers 1992 and 1997.

migrant in the coastal waters of Cyprus may inter alia threaten the Posidonia meadows. The controlling mechanisms for the pronounced growth of $C$. racemosa off the coast of Cyprus are not yet known, but, the inherent dif ferences in the life history traits of this migrant vs. native algal species, the local nutrient dynamics and differences in grazing intensity are likely to be related. Moreover, the high salinities and temperatures occurring in the eastern Mediterranean may be of benefit to its expansion, especially in mild winters. It has recently been suggested that climate change has affected the temperature of the Mediterranean with a notable warming of deep waters [30]. It is likely that the recent increase of water temperature in the Mediterranean will accelerate the proliferation of this Red Sea migrant.

The recent expansion of the macrophytic alga $C$. racemosa has raised the question as to how far this is related to nutrient inputs from sewage discharges and inputs from the fish farm. However, it is considered unlikely that nutrients from the sewage could have an impact on the
Caulerpa and other phytobenthos at this depth. A recent study on the effect of sewage on benthos has shown that the impact was prominent at shallow stations (up to $10 \mathrm{~m}$ depth) [2]. Though some nutrient increases would be pre dicted due to the fish farm, the proliferation of $C$. racemosa in other areas seems to indicate that the proliferation of $C$. racemosa may be unrelated to this source.

Changes in the phytobenthic community in Moni Bay, with the dominance of the macroalgal beds of C. racemosa, may also cause significant changes in macrofaunal assemblages.

Based on the available data from Moni Bay, there is evidence that the recent expansion of C. racemosa in the coastal waters of Cyprus imposed successional changes on the macrofaunal communities with significant increases in species diversity and abundance. These increases are, however, mainly associated with increases in polychaete diversity and abundance. 

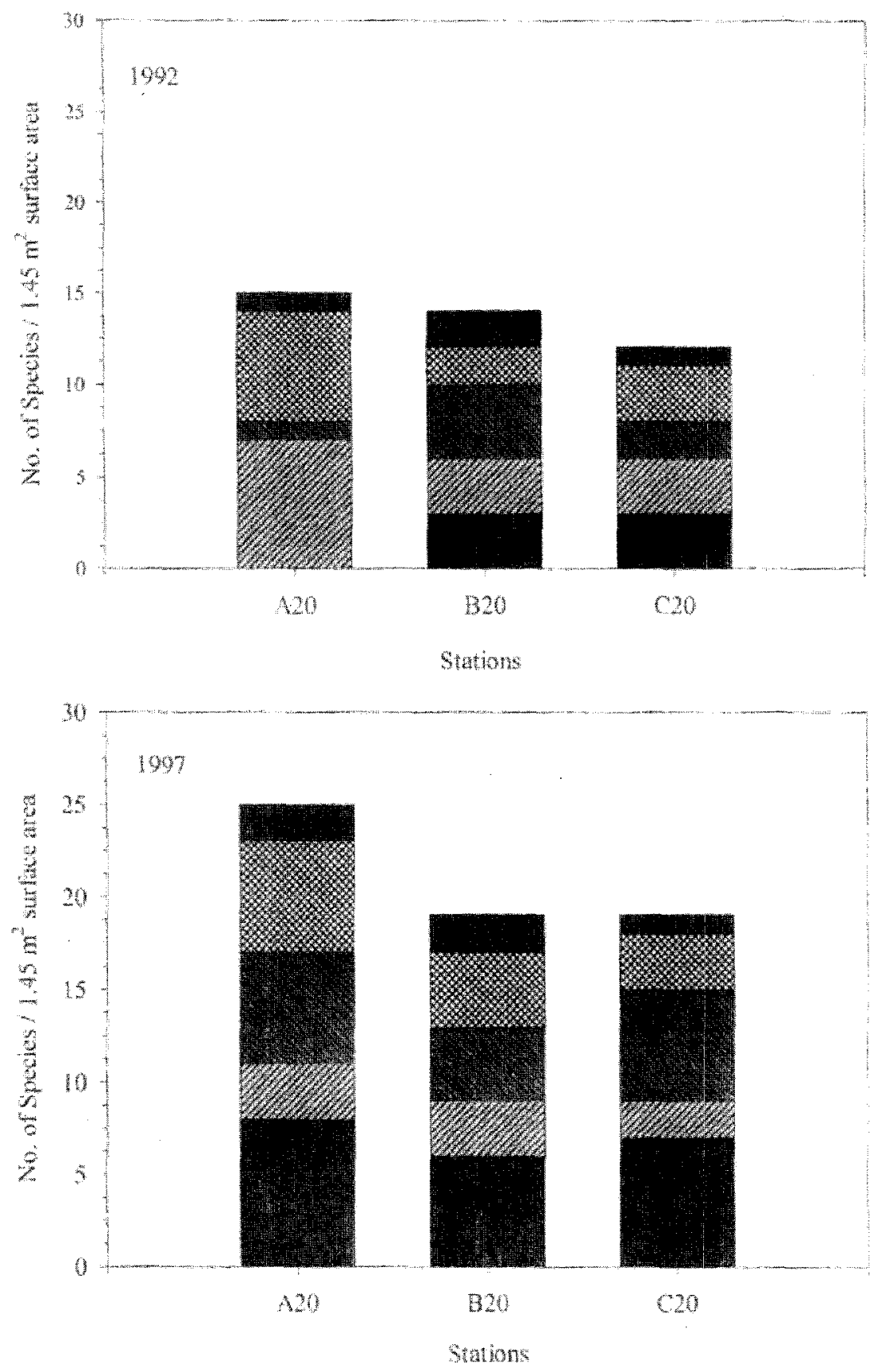

Figure 6. Number of species of the dominant macrofaunal groups per $1.45 \mathrm{~m}^{2}$ surface area, from all three stations of Moni Bay, from summers 1992 and 1997. 


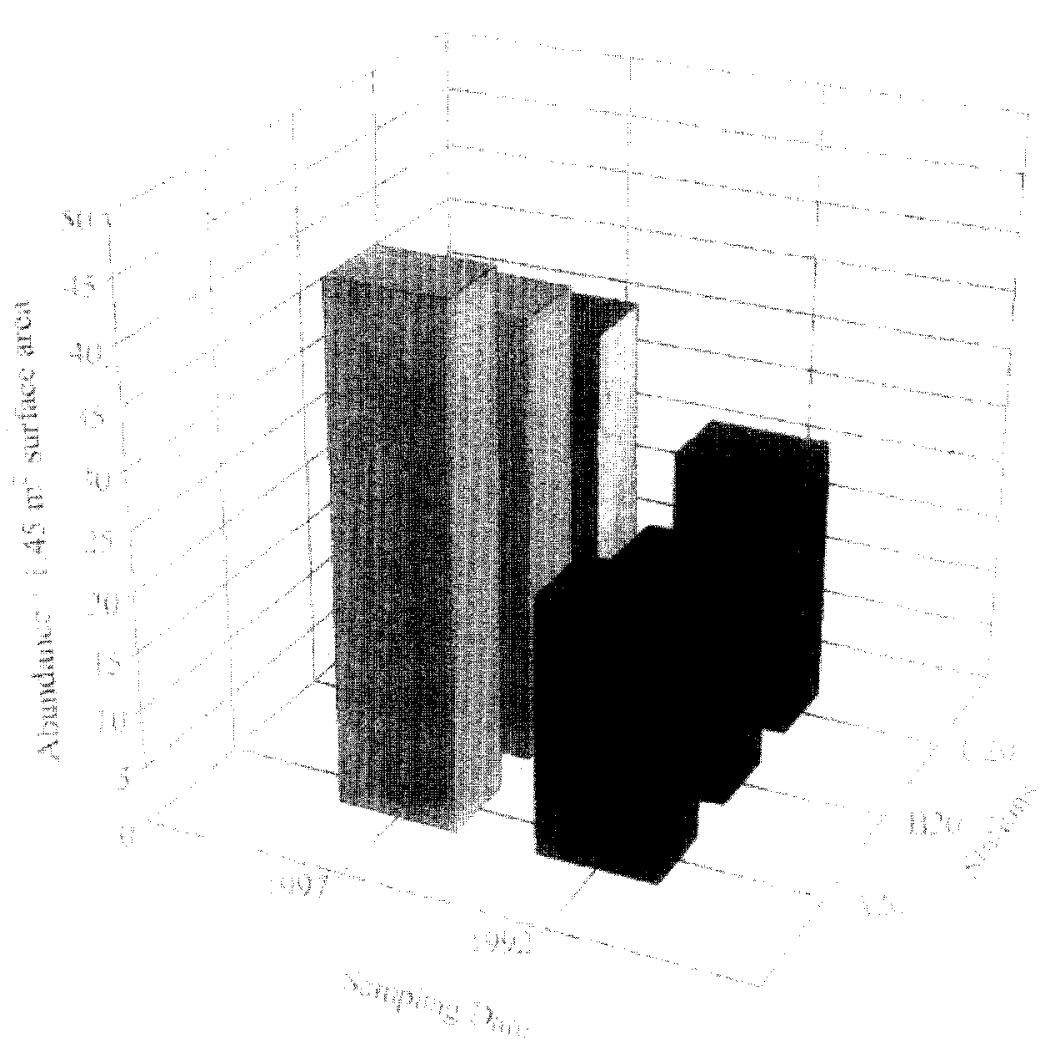

Figure 7. Macrofaunal abundance per $1.45 \mathrm{~m}^{2}$ surface area, from all three stations of Moni Bay, from summers 1992 and 1997.

To understand fully the relationship between the invasive alga $C$. racemosa and the associated macrofaunal assemblages in the coastal waters of Cyprus, more data from other regions around the island are required.

\section{CONCLUSIONS}

On the basis of our field study in Moni Bay, we conclude that:

1. It is likely that the changes in composition and abundance of macrofaunal assemblages are attributable to the recent proliferation of the invasive macroalgal C. racemosa in the coastal waters of Moni Bay. While the most dominant taxon prior to the appearance of C. racemosa was gastropoda with $44 \%$, after the expansion of $C$. racemosa, the most dominant taxon was polychaeta with $38 \%$.

2. There were significant increases in macrofaunal diversity and abundance in 1997 compared to 1992 which are attributed in part at least to the prolific growth of C. racemosa.

3. More data need to be gathered from other regions in Cyprus, where C. racemosa proliferates, in order to support the present data and conclusions.

4. The recent colonization of the Red Sea migrant C. racemosa is still in an evolutionary stage. Whether its expansion in this particular area relates to nutrient inputs and/or to grazing intensity or to inherent differences in the life history traits of this migrant vs. native algal species or to the warming of the waters due to climate change remains to be seen.

\section{Acknowledgements}

The authors thank the crew of the R.V. Alkyon for their assistance in the collection of field samples. They are especially grateful to George Demetriou and Theodora Nicolaidou-Shamma for their invaluable help with field sampling and sample processing. 

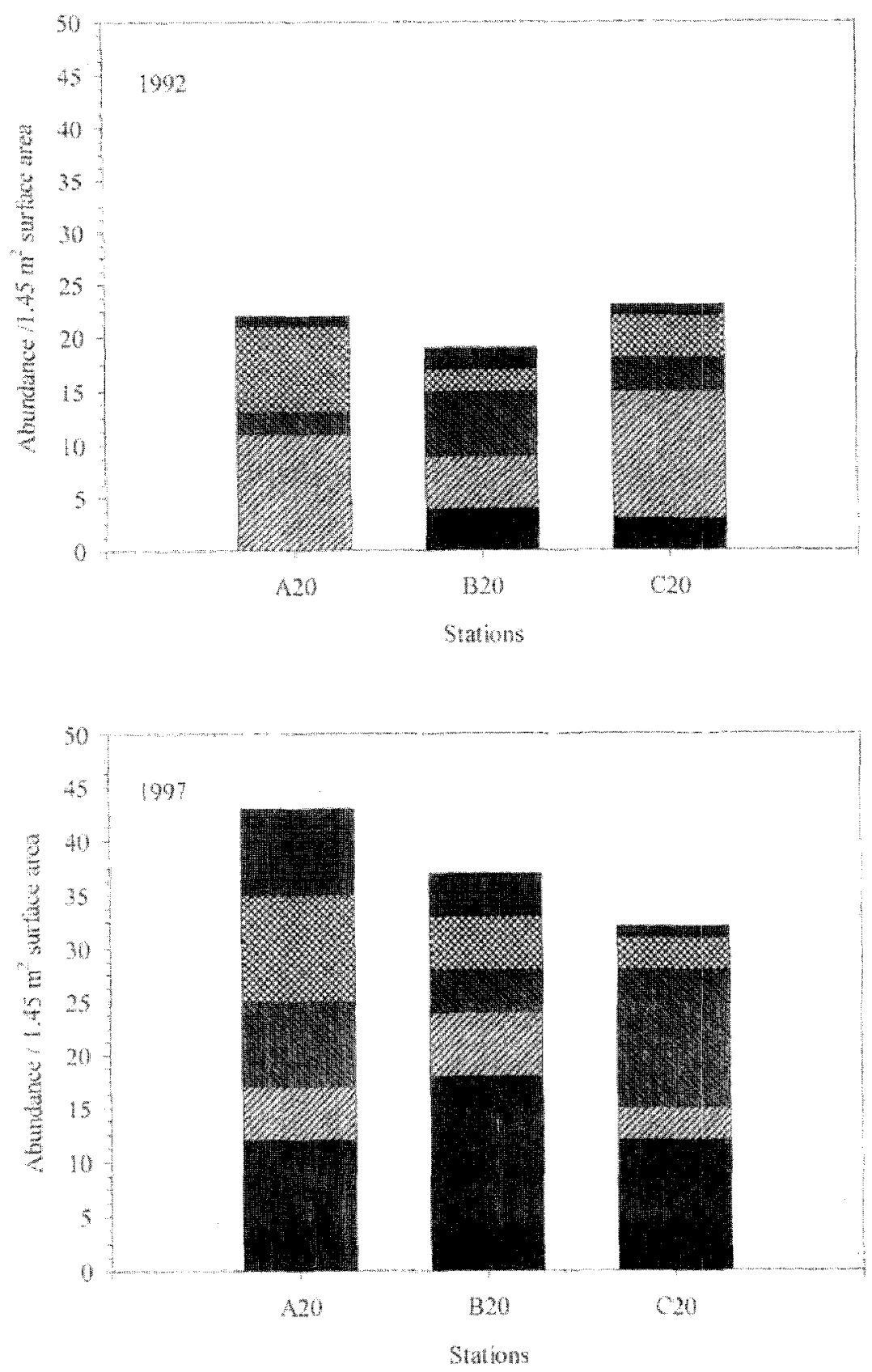

Figure 8. Abundances of the dominant macrofaunal groups per $1.45 \mathrm{~m}^{2}$ surface area, from all three stations of Moni Bay, from summers 1992 and 1997. 
[1] Aleen A.A., The occurrence of the sea-grass: Halophila stipulacea (Forssk.) Asch, on the west coast of Egypt. Bull. Fac. Sci., Univ. Alcxandria 4 (1962) 79-84.

[2] Argyrou M., Hadjichristophorou M., Demetropoulos A., Ecological changes of softbottom macrobenthic assemblages in relation to the sewage outfall, in the Limassol Bay, Cyprus, eastern Mediterranean, Oebalia (accepted).

[3] Bilyard G.R., The value of benthic infauna in marine pollution monitoring studies, Mar. Poll. Bull. 18 (1987) 581-585.

[4] D’Angelo G., Gargiullo S., Guida alle conchiglie Mediteranee, Fabri Editori, Milano, 1987,224 p.

[5] Demetropoulos A., Marine molluses of Cyprus (Part A), Fisheries Bulletin, Ministry Agriculture Nat. Res., Fisheries Dep. $2,1969,1-15$.

[6] Demetropoulos A., Marine molluscs of Cyprus (Part B), Fisheries Bulletin, Ministry Agriculture Nat. Res., Fisheries Dep. $2,1971,1-15$.

[7] Demetropoulos A., Hadjichristophorou M., Echinodermata of Cyprus, Fisheries Bulletin, Ministry Agriculture Nat. Res., Fisheries Dep., 1976a, 1-74.

[8] Demetropoulos A., Hadjichristophorou M., Some additions to the knowledge of the malacofauna of Cyprus, Fisheries Bulletin, Ministry Agriculture Nat. Res., Fisheries Dep. 4, 1976b, $75-83$.

19] Fauvel P., Polychetes errantes, Faune de France, 5, Kraus Reprint, NendIn/Liechtenstein, 1975, 488 p.

[10] Fischer W., Schneider M., Bauchot M. L., Méditerranée et mer Noire, Zones de pêche I (Invertebrates), FAO, Rome, 1987, $760 \mathrm{p}$.

[11] Fredj G., Bellan-Santini D., Meinardi M., Etat des connaissances sur la faune marine méditerranéenne, Bull. Inst. Océanogr., Monaco 9 (1992) 133-145.

[12] Galil B.S., Eritrean decaps in the Levant, Biogeography in motion, Bull. Inst. Océanogr., Monaco 9 (1992) 115-123.

[13] Hadjichristophourou M., Argyrou M., Environmental Impact Assessment Study for Sewerage Scheme of Limassol - Amathus - Marine Ecology Study - Ministry Agriculture Nat. Res., Env. Dep. Fisheries Rep. Cyprus, 1992, 104 p.

[14] Hadjichristophourou M., Argyrou M., List of Marine Plants Recorded in the Coastal Area of Cyprus, Ministry Agriculture Nat. Res., Env. Dep. Fisheries Rep. Cyprus, 1993, 5 p.

[15] Hadjichristophourou M., Argyrou M., Demetropoulos A., Bianchi T.S., A Species List of the Sublittoral Soft-bottom Macrobenthos of Cyprus, Acta Adriat. 38, 1 (1997) 3--32.
[16] Haritonides S., Notes of Phycology, Aristotle Univ. Thessalom niki, Greece, $1983,148 \mathrm{p}$.

[17] Heip C., Eutrophication and zoobenthos dynamics, Ophelia 41 (1995) 113-136.

[18] Ingram R.L., Sieve analysis, in: Carver R.E. (Ed.), Procedures in Sedimentary Petrology, Wiley Interscience, 1971, pp. 49 66.

[19] Kimor B., The Suez Canal as a link and a barrier in the migration of planktonic organisms, Isr. J. Zool. 21 (1972) 381-403.

[20] Lipkin Y., Marine algal and sea-grass flora of the Suez Canal (The significance of this flora to the understanding of the recent migration through the Canal), Isr. J. Zool. 21 (1972) 405-446.

[21] Lipkin Y., Flora and Vegetation in the Suez Canal a hundred years after its opening, in: Hebrew Univ.-Smithsonian Institution Joint Program, Appendix to Research Proposal 1970/71, Dep. Zoology (Ed.), Biota of the Red Sea and the Eastern Mediterranean, The Hebrew Univ. Jerusalem, 1971.

[22] Parenzan P., Carta d'identita delle conchiglie del Mediterraneo II, Bivalvi, Bio Taras Editrice, Taranto, 1976, 546 p.

[23] Por F.D., One hundred years of Suez Canal- A century of Lessepsian migration: Retrospect and viewpoints, Syst. Zool. 20 (1971) $138-159$.

[24] Riedl R., Fauna und Flora des Mittelmeeres, Verlag Paul Parey, $1983,836 \mathrm{p}$.

[25] Sabelli B., Giannuzzi-Savelli R., Bedulli D., Annotated checklist of Mediterranean Marine Molluscs, Libr. Naturalistica Bolognese (Vol. I), 1990, 348 p.

[26] Sokal R.R., Rohlf F.J., Biometry, The principles and practice of Statistics in Biological Research, third Ed., Freeman W.H. and Company, 1995, $887 \mathrm{p}$.

[27] Steinitz H., A tentative list of immigrants via the Suez Canal, Isr. J. Zool. 16 (1967) 166-169.

[28] Steinitz H., Comprehensive list of immigrant animals, in: Hebrew Univ.-Smithsonian Institution Joint Program, Research proposal 1970/71, Dep. Zoology (Ed.), Biota of the Red Sea and the Eastern Mediterranean, The Hebrew Univ. Jerusalem, 1970, pp. 59-63.

[29] Tebble N., British bivalve seashells, Alden Press, 1966, $887 \mathrm{p}$.

[30] Williams N., The Mediterranean Beckons to Europe's Oceanographers. Sci. 279 (1998) 483-484.

[31] Zariquiey A.R., Crustaceos decapodos Ibericos. Inv. Pes 2, 32, (1968) $510 \mathrm{p}$. 